Article

\title{
Synthesis of 3,4-Biaryl-2,5-Dichlorothiophene through Suzuki Cross-Coupling and Theoretical Exploration of Their Potential Applications as Nonlinear Optical Materials
}

\author{
Nasir Mahmood ${ }^{1}$, Nasir Rasool ${ }^{1, *}$, Hafiz Mansoor Ikram ${ }^{1}{ }^{\circledR}$, Muhammad Ali Hashmi ${ }^{2,3}{ }^{(\mathbb{C}}$, \\ Tariq Mahmood ${ }^{4}$, Muhammad Zubair ${ }^{1}$, Gulraiz Ahmad ${ }^{1}$, Komal Rizwan ${ }^{5}$, Tahir Rashid ${ }^{6}$ and \\ Umer Rashid ${ }^{7, *(\mathbb{D})}$ \\ 1 Department of Chemistry, Government College University Faisalabad, Faisalabad 38000, Pakistan; \\ hnmr92@gmail.com (N.M.); chemistue@gmail.com (H.M.I.); zubairmkn@yahoo.co.uk (M.Z.); \\ gulchemist35@gmail.com (G.A.) \\ 2 School of Chemical and Physical Sciences, Victoria University of Wellington, Wellington 6012, New Zealand; \\ i4hashmi@hotmail.com \\ 3 Department of Chemistry, University of Management and Technology, C-II, Johar Town, Lahore 54770, \\ Pakistan \\ 4 Department of Chemistry, COMSATS University, Abbottabad Campus, University Road, Tobe Camp, \\ Abbottabad 22060, Pakistan; mahmood@ciit.net.pk \\ 5 Department of Chemistry, Government College Women University, Faisalabad 38000, Pakistan; \\ komal.rizwan45@yahoo.com \\ 6 State Key Laboratory of Metal Matrix Composites, The School of Chemistry \& Chemical Engineering, \\ Shanghai Jiao Tong University, 800 Dongchuan Road, Shanghai 200240, China; tahir.rasheed@hotmail.com \\ 7 Institute of Advanced Technology, Putra Malaysia, 43400 UPM Serdang, Selangor, Malaysia \\ * Correspondence: nasirrasool@gcuf.edu.pk (N.R.); umer.rashid@upm.edu.my (U.R.); \\ Tel.: +92-332-7491790 (N.R.); +60-3-8946-7393 (U.R.); Fax: +92-41-9201032 (N.R.); +60-3-8946-7006 (U.R.)
}

Received: 22 September 2018; Accepted: 23 October 2018; Published: 18 December 2018

\begin{abstract}
We report herein the efficient one-pot synthesis of 3,4-biaryl-2,5-dichlorothiophene derivatives (2a-2i) via a palladium-catalyzed Suzuki cross-coupling reaction. A series of thiophene derivatives were synthesized, starting from 3,4-dibromo-2,5-dichlorothiophene (1) and various arylboronic acids using $\mathrm{Pd}\left(\mathrm{PPh}_{3}\right)_{4}$ and $\mathrm{K}_{3} \mathrm{PO}_{4}$ with moderate to good yields. For further insights about the structure and property relationship, density functional theory (DFT) calculations were performed. A relaxed potential energy surface (PES) scan was performed to locate the minimum energy structure. A frontier molecular orbitals analysis was performed to explain the reactivity of all synthesized derivatives. As the synthesized derivatives had extended conjugations, therefore the first hyperpolarizability $\left(\beta_{0}\right)$ was calculated to investigate their potential as non-linear optical (NLO) materials and significant $\beta_{o}$ values were found for the $\mathbf{2} \mathbf{b}$ and $\mathbf{2 g}$ derivatives.
\end{abstract}

Keywords: Suzuki cross-coupling reaction; thiophene; $\mathrm{Pd}\left(\mathrm{PPh}_{3}\right)_{4}$; NLO; PES; density functional theory

\section{Introduction}

In 1970, Davydov and co-workers reported the significance of organic materials based on a strong second harmonic generation (SHG) and formulated a base for interest for organic-based systems in non-linear optics (NLO) [1]. The important requirements for being a good non-linear optical material are a high chemical and thermal stability, good transparency and a greater 
non-linear optical coefficient [2,3]. The advanced non-linear optical materials with all of these characteristics are an important area of research in the field of photonics. Over the years, organic chemists have tried to establish such organic materials due to their applications such as they can be used in optical data storage, optical information processing and telecommunications [4-6]. Substituted thiophene derivatives have been of great interest due to their facile synthesis and a broad range of applications in several fields. Thiophene derivatives have been used in the electronics industry such as in electrochromic devices [7], non-linear optics [8], azo-dyes [9], electronic devices [7], electrodes and transistors [10] and energy storage devices [11]. In the past few years, the synthesis of new heterocyclic compounds involving a thiophene ring has attracted a lot of interest due to their diverse and vast applications particularly in non-linear optics [8]. The facile synthesis of thiophene derivatives is largely based on condensation-like reactions. Several innovative approaches have been employed for the formation of these derivatives, however, Suzuki cross-coupling reactions have been shown to be remarkably effective tools for carbon-carbon bond formation. It has emerged as a powerful methodology and can make use of weakly basic heterocyclic compounds and a wide range of organo-boron compounds i.e., arylboronic acids [11]. This coupling-approach is preferred over others because of its ease and moderate conditions of temperature and it tolerates many functionalities. Inspired by this knowledge and in view of the industrial importance of thiophene derivatives, herein, the present investigation aimed to focus on the synthesis of various 3,4-biaryl-2,5-dichlorothiophene derivatives through the reactions of 3,4-dibromo-2,5-dichlorothiophene with different arylboronic acids utilizing palladium-catalyzed Suzuki cross-coupling reactions. Furthermore, the first hyperpolarizability $\left(\beta_{0}\right)$ (which is directly proportional to the NLO response of any compound) of all synthesized derivatives, along with a relaxed PES scan and frontier molecular orbitals (FMOs) analysis, was calculated with the help of density functional theory (DFT) calculations.

\section{Results and Discussion}

\subsection{Chemistry}

Dang and co-workers [12] reported the carbon-carbon coupling reactions between a thiophene-based substrate and a series of different arylboronic acids catalyzed by palladium- $(0)$, leading to the formation of 2,5-biaryl-3,4-dibromothiophene derivatives. Ikram [13] also reported double Suzuki cross-coupling reactions of a thiophene-based substrate with different arylboronic acids in the presence of a palladium-(0) catalyst for the formation of 2,5-biaryl-3-hexylthiophene derivatives. In this context, in the present research work, we have focused on palladium-catalyzed Suzuki cross-coupling reactions for the formation of new thiophene-based derivatives. For this purpose, the synthesis of new thiophene derivatives (2a-2i) was initiated with the commercially available thiophene-based substrate 3,4-dibromo-2,5-dichlorothiophene (1); it was coupled with several arylboronic acids to obtain the desired novel 3,4-biaryl-2,5-dichlorothiophene derivatives by making use of Suzuki cross-coupling reactions. The synthesis of new thiophene-based derivatives is described in Scheme 1.

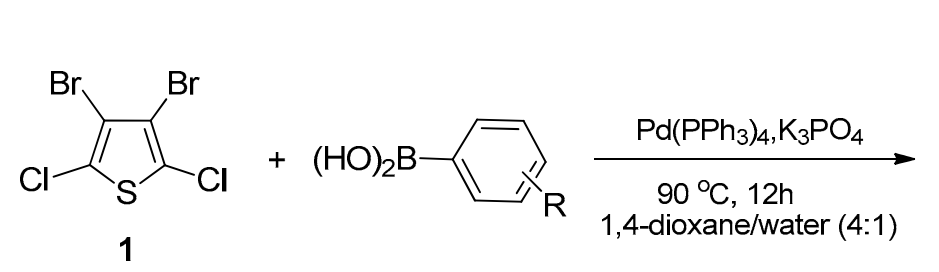

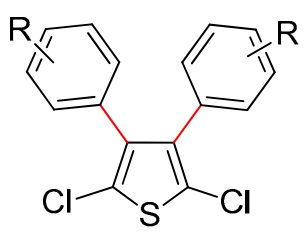

(2a-2i)

Scheme 1. Synthesis of 3,4-biaryl-2,5-dichlorothiophene (2a-2i). Reagents and conditions: $\mathbf{1}$ (1 mmol), arylboronic acids (2 mmol), $\mathrm{Pd}\left(\mathrm{PPh}_{3}\right)_{4}(4 \mathrm{~mol} . \%), \mathrm{K}_{3} \mathrm{PO}_{4}(1.75 \mathrm{mmol})$, solvent/water $(4: 1), 90{ }^{\circ} \mathrm{C}, 12 \mathrm{~h}$. 
The Suzuki cross-coupling reactions of 3,4-dibromo-2,5-dichlorothiophene (1) with several arylboronic acids produced a series of 3,4-biaryl-2,5-dichlorothiophene derivatives (2a-2i) in moderate to good yields (Figure 1). Tetrakis (triphenylphosphine) palladium (0) was utilized to catalyze all of these coupling reactions while potassium phosphate was used as a base to get the desired products. These coupling reactions were performed in a mixture of 1,4-dioxane and water as a solvent in a ratio of $4: 1$, respectively. The temperature was maintained at $90^{\circ} \mathrm{C}$ to carry out these couplings. The best results were obtained with 1,4-dioxane instead of toluene, as the arylboronic acids are highly soluble in 1,4-dioxane [14]. As expected, the corresponding thiophene-based derivatives were obtained in moderate to good yields. Furthermore, different arylboronic acids were used in Scheme 1 and the corresponding products and their yields are listed in Table 1.

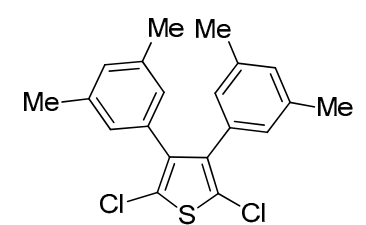

$\mathbf{2 a}$<smiles>Fc1ccc(-c2c(Cl)sc(Cl)c2-c2ccc(F)c(Cl)c2)cc1Cl</smiles>

2d

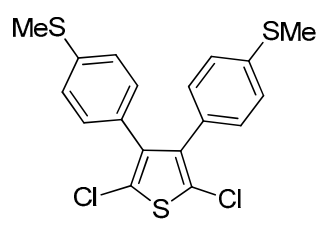

$2 \mathrm{~g}$

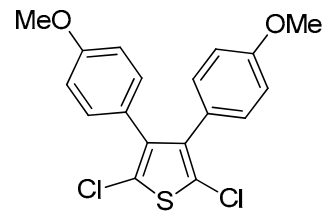

2b

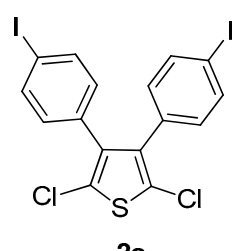

$2 e$

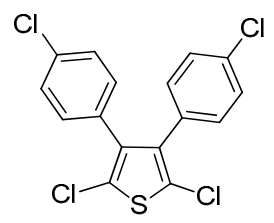

2h

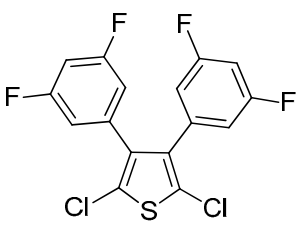

2c
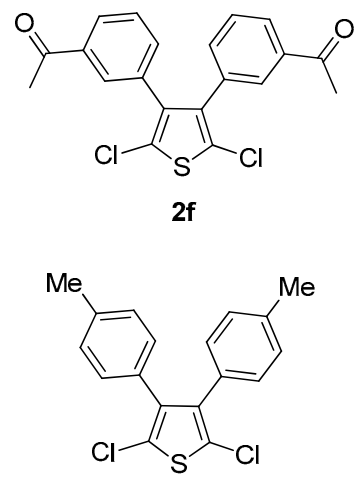

2i

Figure 1. Structures of new 3,4-biaryl-2,5-dichlorothiophene (2a-2i).

Table 1. Synthesis of 3,4-biaryl-2,5-dichlorothiophene (2a-2i).

\begin{tabular}{cccc}
\hline Entry & Arylboronic Acids & Product & Yield \\
\hline 1 & 3,5-dimethylphenylboronic acid & $\mathbf{2 a}$ & 53 \\
2 & 4-methoxyphenylboronic acid & $\mathbf{2 b}$ & 65 \\
3 & 3,5-difluorophenylboronic acid & $\mathbf{2 c}$ & 63 \\
4 & 3-chloro-4-fluorophenylboronic acid & $\mathbf{2 d}$ & 71 \\
5 & 4-iodophenylboronic acid & $\mathbf{2 e}$ & 69 \\
6 & 3-acetylphenylboronic acid & $\mathbf{2 f}$ & 65 \\
7 & 4-(methylthio)phenylboronic acid & $\mathbf{2 g}$ & 74 \\
8 & 4-chlorophenylboronic acid & $\mathbf{2 h}$ & 70 \\
9 & p-tolylboronic acid & $\mathbf{2 i}$ & 57 \\
\hline
\end{tabular}

The experimental results have shown that carbon-carbon coupling occurred at both the 3 and 4 positions of the thiophene ring in each entry. The possible reason for this coupling was the carbon-bromine bond strength, which showed a lower bond energy as compared to the carbon-chlorine bond and, consequently, the carbon-bromine bond showed a significantly greater reactivity towards arylboronic acids. The results have also revealed that the different arylboronic acids bearing electron-donating or electron-withdrawing substituents have different effects on the structure and properties of the synthesized products. To the best of our knowledge, palladium-catalyzed Suzuki 
cross-coupling reactions of 3,4-dibromo-2,5-dichlorothiophene derivatives with various arylboronic acids to prepare 3,4-biaryl-2,5-dichlorothiophene (2a-2i) have not been investigated so far. Furthermore, the first hyperpolarizability $\left(\beta_{o}\right)$ of all synthesized derivatives, along with a relaxed PES scan and frontier molecular orbitals (FMOs) analysis, was calculated with the help of DFT calculations.

\subsection{Computational Methods}

All of the computations were done with Gaussian 09 (Revision D.01) [15]. All of the calculations were performed with density functional theory (DFT) using Adamo's hybrid [16] version of Perdew, Burke and Ernzerhof functional (PBE0) $[17,18]$ along with the application of Grimme's empirical D3 correction with Becke-Johnston damping (D3BJ) [19-21]. Alrich's triplet $\zeta$ basis set Def2-TZVP [22] was used in all the calculations. The calculations used the Polarizable Continuum Model (PCM) with the integral equation formalism variant (IEFPCM) [23-25] for solvation modelling. The PCM model is a fairly old continuum solvation but it is still one of the best solvation methods because of continuing efforts and improvements in its computational efficiency and generality. Due to all of these efforts and improvements in this method, it is a default option in many computational chemistry programs [26]. The SMD parameter set by Cramer and Truhlar [27] (as implemented in Gaussian 09) [15] was used to model the effects of the solvent, which was 1,4-dioxane in all of the calculations. A relaxed potential

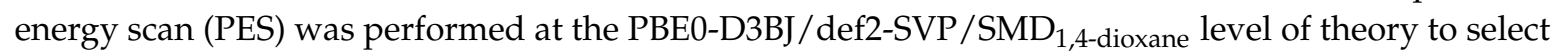
the minima on the potential energy surface. All of the structures were checked to confirm if they were at an energy minimum on the potential energy surface at the PBE0-D3BJ/def2-TZVP/SMD 1,4 -dioxane level by calculating the harmonic force constants, which showed the absence of imaginary frequencies. NLO calculations were accomplished at the same level of theory as the optimizations. A PES scan plot was plotted using GNUPlot software [28] while the 3D images of the optimized molecules were drawn using the GaussView 5.0.9 and CYLview [29] programs.

\subsection{Results and Discussion}

A relaxed potential energy scan was performed on the backbone of all the compounds (2a-2i) to get the minimum energy structures/conformers. Interestingly, many of the structures from the PES had relative energies of $0-3 \mathrm{kcal} / \mathrm{mol}$ with the rest of them being $>5 \mathrm{kcal} / \mathrm{mol}$ than the lowest energy structure (Figure 2). The ones that were $>5 \mathrm{kcal} / \mathrm{mol}$ higher than the lowest energy structure usually had a $<1 \%$ Boltzmann contribution to the ensemble [30] and did not have a considerable contribution towards the properties calculation. The low energy structures end up at the same optimized structure after further unconstrained optimization due to the symmetrical nature of the molecules under study. Therefore, the lowest energy structure from this PES scan was selected and optimized without any constraints followed by the addition of different groups on the aromatic rings to create the structures $\mathbf{2 a}-\mathbf{2 i}$. All of these structures $(\mathbf{2 a}-\mathbf{2 i})$ were then subjected to optimizations at the PBE0-D3BJ/def2-TZVP/SMD ${ }_{1,4-d i o x a n e}$ level of theory followed by frequency calculations to confirm the structures as true minima on the PES with no imaginary frequencies. The optimized structures of all of the compounds are shown in Figure 3. 


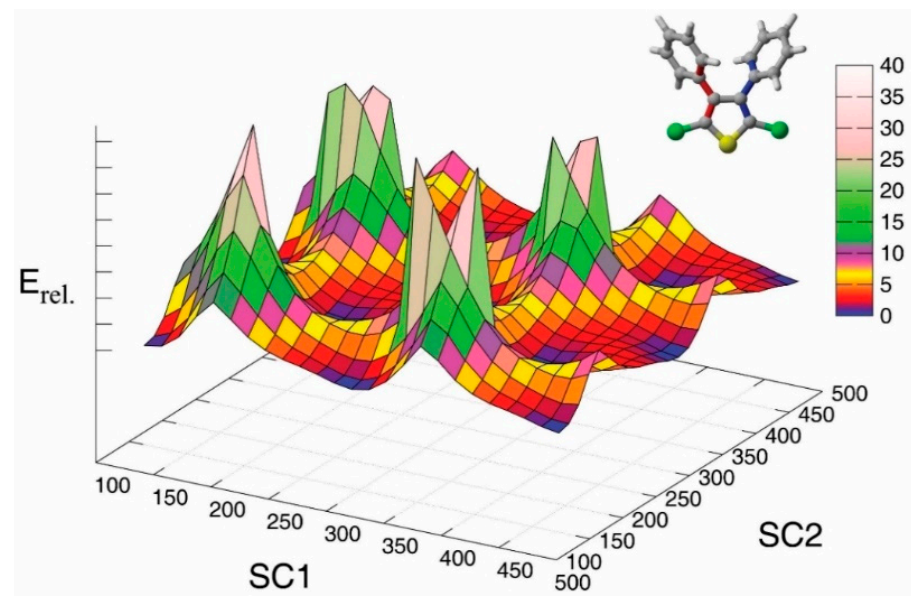

Figure 2. Relaxed potential energy scan on the backbone structure (shown on top) of all the compounds (2a-2i) optimized at the PBE0-D3BJ/def2-SVP/SMD 1 -4-dioxane level of theory. The relaxed scan was performed by rotating two sets of dihedral angles. The first dihedral (SC1) is between atoms whose bonds are shown in blue color while the second one (SC2) is between the atoms whose bonds are shown in red color.

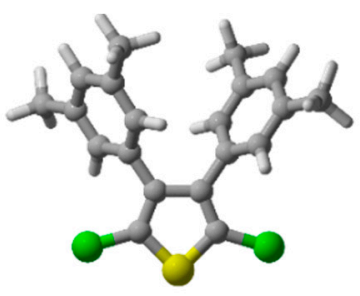

(2a)

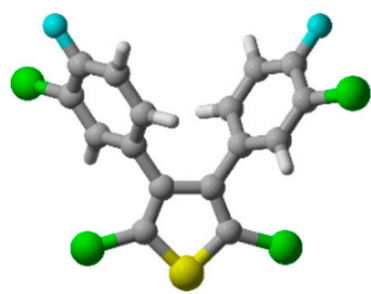

(2d)

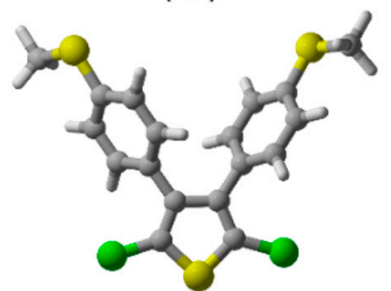

(2g)

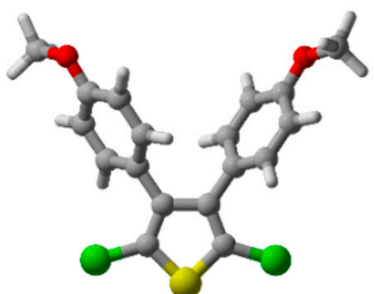

(2b)

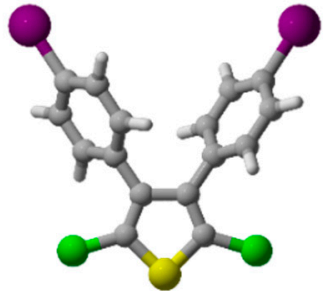

(2e)

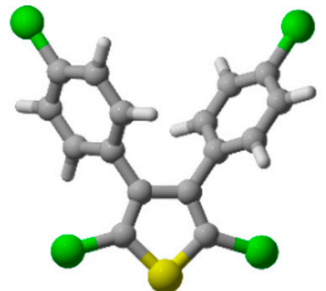

(2h)

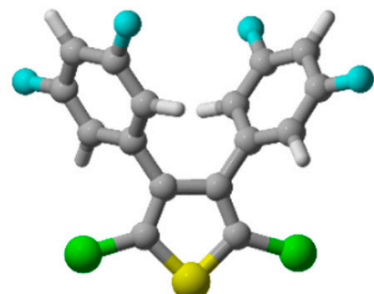

(2c)

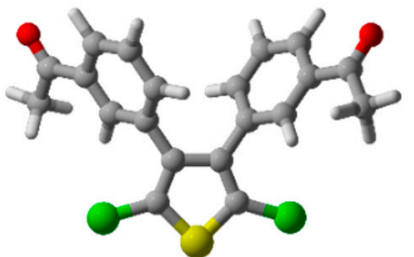

(2f)

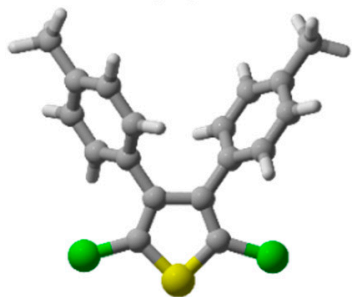

(2i)

Figure 3. Optimized structures of all the compounds (2a-2i) at the PBE0-D3BJ/def2-TZVP/SMD 1,4 -dioxane level of theory. In 3D models, the grey color represents carbon, white represents hydrogens, green is for chlorine atoms, the red color is for oxygen, the yellow color represents sulphur, the magenta color is for iodine, and the light blue color shows fluorine atoms.

\subsubsection{NLO Properties}

There is great interest in the synthesis of materials showing large second-order nonlinear optical (NLO) properties due to their potential applications in imaging technologies, optical computing, sensors, and medicinal applications [31-33]. In organic molecules, the calculated value of the first hyperpolarizability $\left(\beta_{0}\right)$ tells us about the movement of electrons in the molecules between the donor 
and acceptor moieties. The greater the value of $\beta_{0}$, the greater the electrons push-pull mechanism and the NLO response is higher.

In the compounds under study (2a-2i), the phenyl rings act as electron donors while thiophene rings act as an electron acceptor. If there are electron donor groups on the phenyl rings, the electron push-pull mechanism is operating and the $\beta_{o}$ values are higher. If there are electron withdrawing groups on the phenyl moiety, then both ends become electron acceptors and there is no electron push-pull mechanism thus, leading to a low NLO response. In compounds $\mathbf{2 a - 2 i}$, the ones that have strong electron donating groups ( $\mathbf{2} \mathbf{b}$ and $\mathbf{2} \mathbf{g}$ ) have the highest values of hyperpolarizability (Table 2 ). Among these, $\mathbf{2} \mathrm{g}$ had the highest value and bears SMe groups at the para position of the aromatic ring. The lowest $\beta_{o}$ value was observed for $2 \mathrm{c}$ with two $\mathrm{F}$ atoms at positions 3 and 5 of the phenyl rings. These positions of the phenyl ring, when substituted with an electron withdrawing group, make the aromatic ring a strong electron acceptor thus, lowering the NLO response. The compounds with F, I, and $\mathrm{Cl}$ at the para position of the phenyl rings $(\mathbf{2} \mathbf{d}, \mathbf{2 e}$, and $\mathbf{2 h}$ ) have a reasonably better NLO response compared to the ones with electron withdrawing groups at the meta positions ( $\mathbf{2 a}$ and $\mathbf{2} \mathbf{c})$. These results suggest that compounds $\mathbf{2} \mathbf{b}$ and $\mathbf{2 g}$ show the best NLO response and are NLO active compounds.

Table 2. Compounds with their hyperpolarizability and HOMO-LUMO gap values. The units of $\beta_{o}$ are au while the HOMO-LUMO gap is shown in $\mathrm{kcal} / \mathrm{mol}$.

\begin{tabular}{ccc}
\hline Compounds & First Hyperpolarizability & HOMO-LUMO Gap \\
\hline $\mathbf{2 a}$ & 81.08 & 121.14 \\
$\mathbf{2 b}$ & 1361.75 & 118.75 \\
$\mathbf{2 c}$ & 60.73 & 120.63 \\
$\mathbf{2 d}$ & 411.94 & 121.02 \\
$\mathbf{2 e}$ & 693.55 & 117.68 \\
$\mathbf{2 f}$ & 280.27 & 113.25 \\
$\mathbf{2 g}$ & 2807.08 & 110.12 \\
$\mathbf{2 h}$ & 686.95 & 119.33 \\
$\mathbf{2 i}$ & 214.36 & 120.68 \\
\hline
\end{tabular}

\subsubsection{Frontier Molecular Orbital (FMO) Analysis}

Nowadays, FMO analysis is serving as a very important tool to explain the electronic properties of molecules and their reactivity [34]. Electronic transitions mainly arise from the frontier orbitals (HOMO/LUMO) and the HOMO-LUMO energy gap can explain the reactivity and kinetic stability of the compounds [35]. If this energy gap is low, the compound is more reactive and kinetically less stable. An FMO analysis was performed at the same level of theory as the optimizations of the molecules and a plot of all the molecules (2a-2i) is shown in Figure 4. 


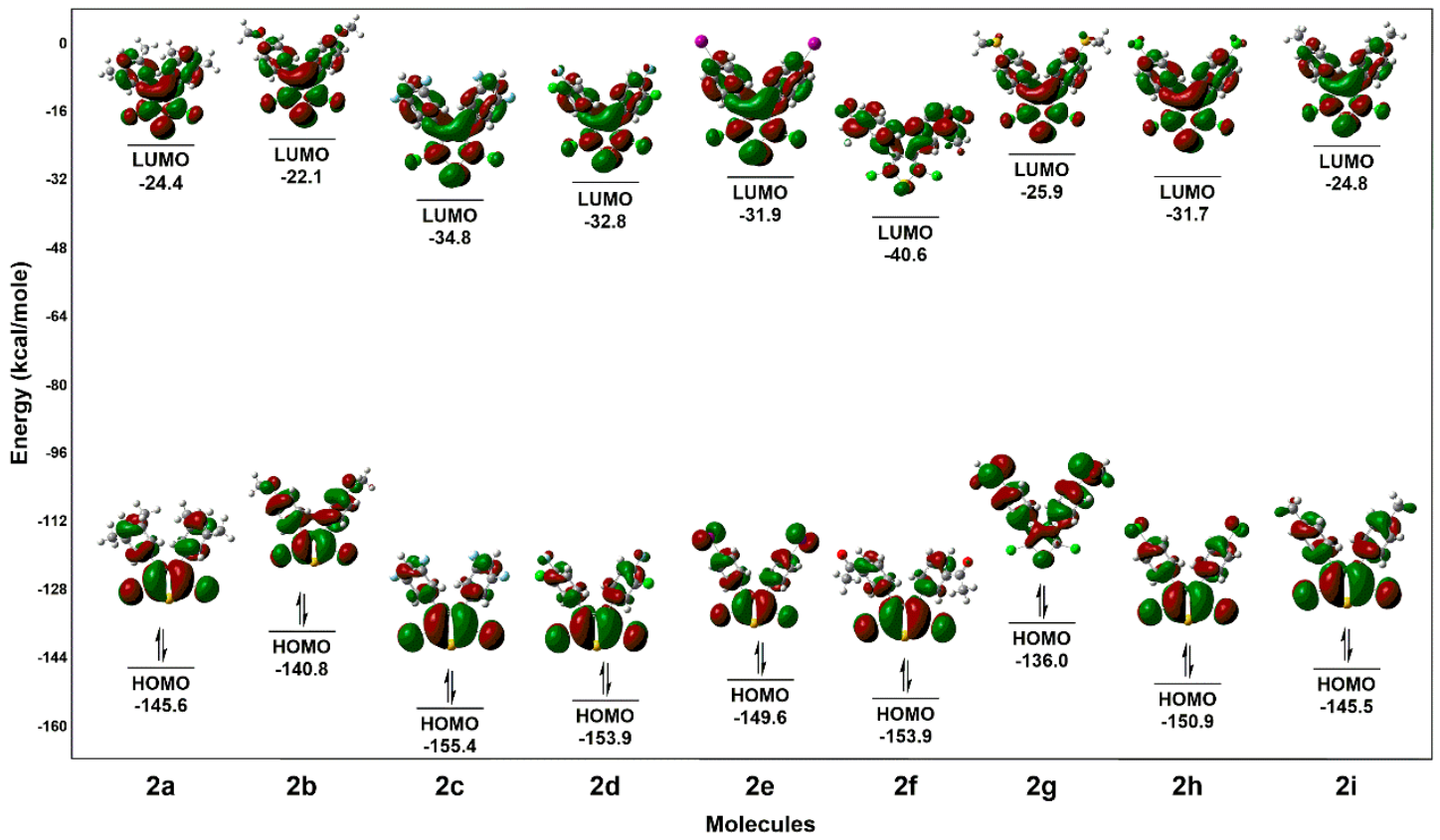

Figure 4. A plot of all the frontier orbitals of all the molecules (2a-2i) calculated at the PBE0-D3BJ/def2-TZVP/SMD 1,4 -dioxane level of theory and arranged according to their relative energies. All of the energies are given in $\mathrm{kcal} / \mathrm{mol}$.

The corresponding HOMO-LUMO energy gap values $(\Delta \mathrm{E})$ are provided in Table 1 . The $\Delta \mathrm{E}$ values of all of the compounds were found in the range $110-121 \mathrm{kcal} / \mathrm{mol}$. Compounds $\mathbf{2 a}, \mathbf{2 c}$, and $\mathbf{2 d}$ had the highest $\Delta \mathrm{E}$ values among all of the others, which makes them the most stable in the series. Interestingly, the compound with the highest NLO response $(\mathbf{2 g})$ was slightly less reactive than the others based on its $\Delta \mathrm{E}$ value of $110.12 \mathrm{kcal} / \mathrm{mol}$ which is still quite a large gap, but it is the lowest in the series $(\mathbf{2 a}-\mathbf{2 i})$.

The iso-density dispersion in the frontier orbitals showed a similar trend for all of the compounds except $\mathbf{2 g}$. For all of the compounds other than $\mathbf{2 g}$, the iso-density was dispersed over the whole molecule, mainly on the phenyl rings, thiophene ring, and the chlorine atoms attached to the thiophene ring. For $2 \mathrm{~g}$, where SMe groups were attached on the phenyl ring, the HOMO iso-density shifted from the thiophene ring and its chlorines towards the SMe groups attached to the phenyl ring. That also explained its lowest $\Delta \mathrm{E}$ value and increase reactivity compared to the rest of the molecules in the series. There is one interesting thing here about $2 \mathbf{e}$ and $\mathbf{2 h}$ where there is an iodine and chlorine atom at the para position of each phenyl ring and the electron density was also delocalized on these halogen atoms along with the phenyl ring.

\section{Experimental}

\subsection{General}

The ${ }^{13} \mathrm{C}$ - and ${ }^{1} \mathrm{H}-\mathrm{NMR}$ data were obtained in a mixture of $\mathrm{CDCl}_{3}$ and $\mathrm{CD}_{3} \mathrm{OD}(9: 1)$ on a Bruker Aspect AM-400 spectrometer at $500 \mathrm{MHz}$ and Tetramethylsilane (TMS) was taken as internal standard. All the chemicals used in this research work were purchased from Sigma-Aldrich, Alfa-Aesar and Merck. EI-MS data were obtained by using a JMS-HX-110 spectrometer. The newly synthesized products were examined through an ultraviolet lamp at wavelengths ranging from 254 to $365 \mathrm{~nm}$.

\subsection{General Method for the Synthesis of 3,4-Biaryl-2,5-Dichlorothiophene (2a-2i)}

An oven dried schlenk flask with a magnetic stirrer and a septum inlet along with a reflux condenser filled with argon gas was used to carry out the reactions. In the schlenk flask, 1,4 dioxane 
(2 mL), 3,4-dibromo-2,5-dichlorothiophene $(0.2 \mathrm{~g}, 1 \mathrm{mmol})$ and $\mathrm{Pd}\left(\mathrm{PPh}_{3}\right)_{4}(0.03 \mathrm{~g}, 4 \mathrm{~mol} . \%)$ was added at $25{ }^{\circ} \mathrm{C}$. After stirring the reaction mixture for $\sim 30 \mathrm{~min}$, arylboronic acid $(1 \mathrm{mmol})$, potassium phosphate $(0.22 \mathrm{~g}, 1.75 \mathrm{mmol})$ and water $(0.5 \mathrm{~mL})$ was added to the above mixture. The mixture was stirred at a temperature of $90{ }^{\circ} \mathrm{C}$ for a period of $12 \mathrm{~h}$. The reaction was monitored by TLC and a mixture of $n$-hexane $(65-90 \%)$ and ethylacetate $(10-35 \%)$ was used as the eluent for TLC. On completion of the reaction, the mixture was cooled down to a normal temperature, filtered and concentrated by rotary evaporation. The purification of the resultant residue was performed by column chromatography. The eluate was dried, recrystallize and further analyzed using different spectroscopic techniques $[13,36,37]$.

\subsection{Characterization Data}

2,5-Dichloro-3,4-bis(3,5-Dimethylphenyl)thiophene (2a). M.P, $215-217^{\circ} \mathrm{C} . R_{f}: 0.84$. (n-hexane $=9.0 \mathrm{~mL}$ : ethyl acetate $=1.0 \mathrm{~mL}) .{ }^{1} \mathrm{H}-\mathrm{NMR}\left(\mathrm{CDCl}_{3}+\mathrm{CD}_{3} \mathrm{OD}\right) \delta=7.80(\mathrm{~d}, J=7.98 \mathrm{~Hz}, 4 \mathrm{H}$-aryl $), \delta=7.45(\mathrm{t}$, $J=7.79,2 \mathrm{H}$-aryl $), 2.29\left(\mathrm{~s}, 12 \mathrm{H}-4 \mathrm{CH}_{3}\right) ;{ }^{13} \mathrm{C}-\mathrm{NMR}\left(\mathrm{CDCl}_{3}+\mathrm{CD}_{3} \mathrm{OD}\right) \delta 21.8,125.1,129.2,130.7,135.3$, 136.2, 138.6. EIMS $m / z$ (+ion mode): 361.29: $[\mathrm{M}-2 \mathrm{Cl}]^{+}=290.38:\left[\mathrm{M}-4\right.$ methyl ${ }^{+}=230.41:\left[\mathrm{M}-\right.$ phenyl $^{+}$ $=155.15:[\mathrm{M} \text { - thiophene }]^{+}=75.05$. Anal. Calcd. for $\mathrm{C}_{20} \mathrm{H}_{18} \mathrm{Cl}_{2} \mathrm{~S}$ (361.35): C, 66.05; H, 5.01. Found: $\mathrm{C}$, $65.95 ; \mathrm{H}, 5.05 \%$.

2,5-Dichloro-3,4-bis(4-Methoxyphenyl)thiophene (2b). M.P, $227^{\circ} \mathrm{C} . R_{f}: 0.82$. (n-hexane $=8.5 \mathrm{~mL}$ : ethyl acetate $=1.5 \mathrm{~mL}) .{ }^{1} \mathrm{H}-\mathrm{NMR}\left(400 \mathrm{MHz}, \mathrm{CDCl}_{3}\right) \delta: 7.49(\mathrm{~d}, J=8.28,4 \mathrm{H}-\mathrm{Ar}), 7.11(\mathrm{~d}, J=5.99,4 \mathrm{H}-\mathrm{Ar})$, 3.78 (s, 6H-methoxy); ${ }^{13} \mathrm{C}-\mathrm{NMR}\left(\mathrm{CDCl}_{3}+\mathrm{CD}_{3} \mathrm{OD}\right) \delta 55.8,114.9,128.2,129.5,130.1,135.6,160.5$. EIMS $m / z$ (+ion mode): 363.29: $[\mathrm{M}-2 \mathrm{Cl}]^{+}=294.01:\left[\mathrm{M}-2 \mathrm{OCH}_{3}\right]^{+}=232.06:[\mathrm{M} \text { - phenyl }]^{+}=155.97:$ $[\mathrm{M} \text { - thiophene }]^{+}=$76.02. Anal. Calcd. for $\mathrm{C}_{18} \mathrm{H}_{14} \mathrm{Cl}_{2} \mathrm{O}_{2} \mathrm{~S}$ (366.20): $\mathrm{C}, 59.10 ; \mathrm{H}, 3.81$. Found: $\mathrm{C}, 58.85$; $\mathrm{H}, 3.70 \%$.

2,5-Dichloro-3,4-bis(3,5-Difluorophenyl)thiophene (2c). M.P, 237-240 ${ }^{\circ} \mathrm{C} . R_{f}$ : 0.66. (n-hexane $=8.5 \mathrm{~mL}$ : ethyl acetate $=1.5 \mathrm{~mL}) .{ }^{1} \mathrm{H}-\mathrm{NMR}\left(400 \mathrm{MHz}, \mathrm{CDCl}_{3}\right) \delta: 7.35(\mathrm{~s}, 4 \mathrm{H}-\mathrm{Ar}), 6.85(\mathrm{~s}, 4 \mathrm{H}-\mathrm{Ar}) .{ }^{13} \mathrm{C}-\mathrm{NMR}\left(\mathrm{CDCl}_{3}+\right.$ $\left.\mathrm{CD}_{3} \mathrm{OD}\right) \delta 104.8,111.6,129.5,135.2,139.7,165.1$. EIMS $m / z$ (+ion mode): 377.21: $[\mathrm{M}-2 \mathrm{Cl}]^{+}=306.04$ : $[\mathrm{M}-4 \mathrm{~F}]^{+}=229.98:[\mathrm{M}-\text { phenyl }]^{+}=155.03:[\mathrm{M} \text { - thiophene }]^{+}=75.04$. Anal. Calcd. for $\mathrm{C}_{16} \mathrm{H}_{6} \mathrm{Cl}_{2} \mathrm{~F}_{4} \mathrm{~S}$ (377.15): C, 50.91; H, 1.56. Found: C, 50.79; H, 1.48\%.

2,5-Dichloro-3,4-bis(3-Chloro-4-Fluorophenyl)thiophene (2d). M.P, $220{ }^{\circ} \mathrm{C} . R_{f}$ : 0.56. (n-hexane $=7.0 \mathrm{~mL}$ : ethyl acetate $=3.0 \mathrm{~mL}) .{ }^{1} \mathrm{H}-\mathrm{NMR}\left(400 \mathrm{MHz}, \mathrm{CDCl}_{3}\right) \delta: 7.99(\mathrm{~s}, 2 \mathrm{H}-\mathrm{Ar}), 7.69(\mathrm{~d}, J=7.89,12 \mathrm{H}-\mathrm{Ar})$, $7.25(\mathrm{~d}, J=6.29,2 \mathrm{H}-\mathrm{Ar}) .{ }^{13} \mathrm{C}-\mathrm{NMR}\left(\mathrm{CDCl}_{3}+\mathrm{CD}_{3} \mathrm{OD}\right) \delta 117.5,121.3,128.5,129,129.9,133.5,135.1$, 158.6. EIMS $m / z$ (+ion mode): 410.69: $[\mathrm{M}-4 \mathrm{Cl}]^{+}=268.05:[\mathrm{M}-2 \mathrm{~F}]^{+}=230.01:\left[\mathrm{M}-\right.$ phenyl ${ }^{+}=154.98$ : $[\mathrm{M} \text { - thiophene }]^{+}=75.02$. Anal. Calcd. for $\mathrm{C}_{16} \mathrm{H}_{6} \mathrm{Cl}_{4} \mathrm{~F}_{2} \mathrm{~S}$ (410.05): $\mathrm{C}, 46.81 ; \mathrm{H}, 1.45$. Found: $\mathrm{C}, 46.75 ; \mathrm{H}$, $1.38 \%$.

2,5-Dichloro-3,4-bis(4-Iodophenyl)thiophene (2e). M.P, $219^{\circ} \mathrm{C} . R_{f}:$ 0.68. $(\mathrm{n}$-hexane $=8.0 \mathrm{~mL}$ : ethyl acetate $=$ $2.0 \mathrm{~mL}$ ). ${ }^{1} \mathrm{H}-\mathrm{NMR}\left(400 \mathrm{MHz}, \mathrm{CDCl}_{3}\right) \delta: 7.59$ (d, $\left.J=8.09,4 \mathrm{H}-\mathrm{Ar}\right), 7.95$ (d, $\left.J=6.31,4 \mathrm{H}-\mathrm{Ar}\right) .{ }^{13} \mathrm{C}-\mathrm{NMR}$ $\left(\mathrm{CDCl}_{3}+\mathrm{CD}_{3} \mathrm{OD}\right) \delta 94.5,129.5,130.1,135.2,135.9,138.2$. EIMS $m / z$ (+ion mode): 555.90: $[\mathrm{M}-2 \mathrm{I}]^{+}$ $=$ 302.03: $[\mathrm{M}-2 \mathrm{Cl}]^{+}=231.97:[\mathrm{M}-\text { phenyl }]^{+}=155.01:[\mathrm{M}-\text { thiophene }]^{+}=76.04$. Anal. Calcd. for $\mathrm{C}_{16} \mathrm{H}_{8} \mathrm{Cl}_{2} \mathrm{I}_{2} \mathrm{~S}$ (557.0): $\mathrm{C}, 34.45 ; \mathrm{H}, 1.42$. Found: $\mathrm{C}, 34.37 ; \mathrm{H}, 1.35 \%$.

1,1'-((2,5-Dichlorothiophene-3,4-diyl)bis(3,1-Phenylene))diethanone (2f). M.P, 227-230 ${ }^{\circ} \mathrm{C} . R_{f}: 0.72$. $(\mathrm{n}$-hexane $=9.0 \mathrm{~mL}$ : Ethyl acetate $=1.0 \mathrm{~mL}) .{ }^{1} \mathrm{H}-\mathrm{NMR}\left(400 \mathrm{MHz}, \mathrm{CDCl}_{3}\right)$ 8: 8.51(t, 2H-Ar), 8:7.90 $(\mathrm{d}$, 2H-Ar), $8: 7.71$ (dd,2H-Ar), $8: 7.35$ (s, 4H-Ar), 6.79 (s, 4H-Ar), 2.60 (t, J = 7.74, 6H-methoxy). ${ }^{13} \mathrm{C}-\mathrm{NMR}$ $\left(\mathrm{CDCl}_{3}+\mathrm{CD}_{3} \mathrm{OD}\right) \delta 26.7,126.2,128.3,129.6,131.8,135.1,136.2,137.3,197.1$. EIMS $m / z$ (+ion mode): 389.21: $[\mathrm{M}-2 \mathrm{Cl}]^{+}=318.02:\left[\mathrm{M}-2 \mathrm{COCH}_{3}\right]^{+}=232.07:[\mathrm{M}-\text { phenyl }]^{+}=156.03:\left[\mathrm{M}-\right.$ thiophene $^{+}=76.05$. Anal. Calcd. for $\mathrm{C}_{20} \mathrm{H}_{14} \mathrm{Cl}_{2} \mathrm{O}_{2} \mathrm{~S}$ (389.25): C, 61.65; H, 3.59. Found: $\mathrm{C}, 61.59 ; \mathrm{H}, 3.55 \%$.

2,5-Dichloro-3,4-bis(4-(Methylthio)phenyl)thiophene (2g). M.P, $174{ }^{\circ} \mathrm{C} . R_{f}$ : 0.77. (n-hexane $=6.5 \mathrm{~mL}$ : ethyl acetate $=3.5 \mathrm{~mL}) .{ }^{1} \mathrm{H}-\mathrm{NMR}\left(400 \mathrm{MHz}, \mathrm{CDCl}_{3}\right) \delta: 7.98(\mathrm{~s}, 1 \mathrm{H}-\mathrm{Ar}), 7.69(\mathrm{~d}, J=7.89,1 \mathrm{H}-\mathrm{Ar}), 7.19(\mathrm{~d}$, 
$J=6.41,1 \mathrm{H}-\mathrm{Ar}), 6.91\left(\mathrm{~s}, 1 \mathrm{H}\right.$-thiophene), $2.71\left(\mathrm{t}, J=7.71,2 \mathrm{H}-\mathrm{CH}_{2}\right), 1.42\left(\mathrm{~m}, 6 \mathrm{H}-\mathrm{CH}_{2}\right), 1.29\left(\mathrm{~m}, 2 \mathrm{H}-\mathrm{CH}_{2}\right)$, $0.79\left(\mathrm{t}, J=5.0993 \mathrm{H}\right.$-methyl). ${ }^{13} \mathrm{C}-\mathrm{NMR}\left(\mathrm{CDCl}_{3}+\mathrm{CD}_{3} \mathrm{OD}\right) \delta 15.9,127.1,127.9,129.4,132.9,135.2,139.5$. EIMS $m / z$ (+ion mode): 396.10: $[\mathrm{M}-2 \mathrm{SMe}]^{+}=302.04:[\mathrm{M}-2 \mathrm{Cl}]^{+}=232.07:[\mathrm{M}-\text { phenyl }]^{+}=156.05$ : $[\mathrm{M} \text { - thiophene }]^{+}=$76.06. Anal. Calcd. for $\mathrm{C}_{18} \mathrm{H}_{14} \mathrm{Cl}_{2} \mathrm{~S}_{3}$ (397.38): $\mathrm{C}, 54.38 ; \mathrm{H}, 3.51$. Found: $\mathrm{C}, 54.35 ; \mathrm{H}$, $3.45 \%$.

2,5-Dichloro-3,4-bis (4-Chlorophenyl)thiophene (2h). M.P, $210^{\circ} \mathrm{C} . R_{f}$ : 0.68. (n-hexane $=8.5 \mathrm{~mL}$ : ethyl acetate $=1.5 \mathrm{~mL}) .{ }^{1} \mathrm{H}-\mathrm{NMR}\left(400 \mathrm{MHz}, \mathrm{CDCl}_{3}\right) \delta: 7.68(\mathrm{~d}, J=8.09,2 \mathrm{H}-\mathrm{Ar}), 7.45(\mathrm{~d}, J=6.22,2 \mathrm{H}-\mathrm{Ar}), 6.92(\mathrm{~s}$, 1H-thiophene) 2.47 (s, 3H-thiomethyl), $2.59\left(\mathrm{t}, J=7.49,2 \mathrm{H}-\mathrm{CH}_{2}\right), 1.25\left(\mathrm{~m}, 6 \mathrm{H}-\mathrm{CH}_{2}\right), 1.18\left(\mathrm{~m}, 2 \mathrm{H}-\mathrm{CH}_{2}\right)$, $0.79\left(\mathrm{t}, J=6.09,3 \mathrm{H}\right.$-methyl). ${ }^{13} \mathrm{C}-\mathrm{NMR}\left(\mathrm{CDCl}_{3}+\mathrm{CD}_{3} \mathrm{OD}\right) \delta 128.8,129.5,134.1,134.9,136.1$. EIMS $\mathrm{m} / \mathrm{z}$ (+ion mode): $373.95:[\mathrm{M}-4 \mathrm{Cl}]^{+}=231.98:\left[\mathrm{M}-\right.$ phenyl $^{+}=155.99:[\mathrm{M} \text { - thiophene }]^{+}=76.08$. Anal. Calcd. for $\mathrm{C}_{16} \mathrm{H}_{8} \mathrm{Cl}_{4} \mathrm{~S}$ (374.07): C, 51.35; $\mathrm{H}, 2.11$. Found: $\mathrm{C}, 51.31 ; \mathrm{H}, 2.06 \%$.

2,5-Dichloro-3,4-di-p-Tolylthiophene (2i). M.P, $223{ }^{\circ} \mathrm{C} . R_{f}$ : 0.80. (n-hexane $=9.0 \mathrm{~mL}$ : ethyl acetate $=1.0 \mathrm{~mL}$ ). ${ }^{1} \mathrm{H}-\mathrm{NMR}\left(400 \mathrm{MHz}, \mathrm{CDCl}_{3}\right) \delta: 8.78$ (s, 2H-Ar), 8.11 (d, $\left.J=7.58,2 \mathrm{H}-\mathrm{Ar}\right), 7.56(\mathrm{t}, J=7.85,2 \mathrm{H}-\mathrm{Ar}), 7.89$ $(\mathrm{d}, J=7.38,2 \mathrm{H}-\mathrm{Ar}), 2.52\left(\mathrm{~s}, 6 \mathrm{H}-\mathrm{CH}_{3}\right) .{ }^{13} \mathrm{C}-\mathrm{NMR}\left(\mathrm{CDCl}_{3}+\mathrm{CD}_{3} \mathrm{OD}\right) \delta 21.3,127.3,129.1,129.9,131.9$, 133.6, 135. EIMS $m / z$ (+ion mode): 332.11: $[\mathrm{M}-2 \mathrm{Cl}]^{+}=262.15:[\mathrm{M}-2 \text { methyl }]^{+}=232.17:[\mathrm{M}-\text { phenyl }]^{+}$ $=155.95:[\mathrm{M} \text { - thiophene }]^{+}=$76.01. Anal. Calcd. for $\mathrm{C}_{18} \mathrm{H}_{14} \mathrm{Cl}_{2} \mathrm{~S}$ (333.25): C, 64.85; H, 4.20. Found: $\mathrm{C}$, $64.75 ; \mathrm{H}, 4.15 \%$.

\section{Conclusions}

In conclusion, the palladium-catalyzed Suzuki cross-coupling reaction was employed to synthesize a series of 3,4-biaryl-2,5-dichlorothiophene derivatives (2a-2i) in moderate to good yield. The substrate 3,4-dibromo-2,5-dichlorothiophene (1) and several arylboronic acids were reacted together to produce the desired thiophene-based derivatives. $\mathrm{Pd}\left(\mathrm{PPh}_{3}\right)_{4}$ was used as a catalyst and $\mathrm{K}_{3} \mathrm{PO}_{4}$ as a base to promote the formation of the products. The first hyperpolarizability values show that all synthesized derivatives had a potential NLO response but $\mathbf{2 b}$ and $\mathbf{2} \mathbf{g}$ had significant NLO potential due their large $\beta_{o}$ (1361.75 and $2807.08 \mathrm{au}$, respectively) values. The $\Delta \mathrm{E}$ values for all of the synthesized compounds were found in the range $110-121 \mathrm{kcal} / \mathrm{mol}$, which indicated that all of the compounds were quite stable.

Author Contributions: For this research article, all authors have various contributions "conceptualization, N.R.; methodology, G.A.; software, M.A.H. and T.M.; validation, U.R.; formal analysis, M.A.H. and T.M.; investigation, U.R.; resources, M.Z.; data curation, N.M.; writing-original draft preparation, H.M.I.; writing-review and editing, K.R.; visualization, T.R.; supervision, N.R.; project administration, N.R.

za Funding: This research received no external funding.

Acknowledgments: The present data are the part of M. Phil thesis research work of Nasir Mahmood. The authors also gratefully acknowledge the financial support by the Higher Education Commission of Pakistan. Additional computer time was given by the Victoria University of Wellington High Performance Computer Facilities SciFacHPC and Heisenberg. The authors are highly thankful to the Universiti Putra Malaysia (UPM), Malaysia for the assistance to pay the article processing charges.

Conflicts of Interest: The authors declare no conflicts of interest.

\section{References}

1. Davydov, B.; Derkacheva, L.; Dunina, V.; Zhabotinskii, M.; Zolin, V.; Koreneva, L.; Samokhina, M. Connection between charge transfer and laser second harmonic generation. JETP Lett. 1970, 12, 24-26.

2. Perry, J.; Mansour, K.; Lee, I.-Y.; Wu, X.-L.; Bedworth, P.; Chen, C.-T.; Ng, D.; Marder, S.; Miles, P.; Wada, T. Organic optical limiter with a strong nonlinear absorptive response. Science 1996, 273, 1533-1536. [CrossRef]

3. Fakis, M.; Tsigaridas, G.; Polyzos, I.; Giannetas, V.; Persephonis, P.; Spiliopoulos, I.; Mikroyannidis, J. Intensity dependent nonlinear absorption of pyrylium chromophores. Chem. Phys. Lett. 2001, 342, $155-161$. [CrossRef]

4. Munn, R.W.; Ironside, C. Principles and Applications of Nonlinear Optical Materials; Springer: Berlin, Germany, 1993. 
5. Kuzyk, M.G.; Dirk, C.W. Characterization Techniques and Tabulations for Organic Nonlinear Optical Materials; Marcel Dekker: New York, NY, USA, 1998.

6. McCahon, S.W.; Tutt, L.W.; Klein, M.B.; Valley, G.C. Optical Limiting with Reverse Saturable Absorbers; Electro-Optical Materials for Switches, Coatings, Sensor Optics, and Detectors; International Society for Optics and Photonics: Orlando, FL, USA, 1990; pp. 304-314.

7. Puterová, Z.; Krutošíková, A.; Végh, D. Gewald reaction: Synthesis, properties and applications of substituted 2-aminothiophenes. Arkivoc 2010, 1, 209-246.

8. Cui, Y.; Zhang, X.; Jenekhe, S.A. Thiophene-linked polyphenylquinoxaline: A new electron transport conjugated polymer for electroluminescent devices. Macromolecules 1999, 32, 3824-3826. [CrossRef]

9. Steybe, F.; Effenberger, F.; Beckmann, S.; Krämer, P.; Glania, C.; Wortmann, R. Enhanced nonlinear optical properties and thermal stability of donor-acceptor substituted oligothiophenes. Chem. Phys. 1997, 219, 317-331. [CrossRef]

10. Glenis, S.; Tourillon, G.; Garnier, F. Photoelectrochemical properties of thin films of polythiophene and derivatives: Doping level and structure effects. Thin Solid Films 1984, 122, 9-17. [CrossRef]

11. Huynh, W.U.; Dittmer, J.J.; Alivisatos, A.P. Hybrid nanorod-polymer solar cells. Science 2002, 295, $2425-2427$. [CrossRef] [PubMed]

12. Dang, T.T.; Rasool, N.; Dang, T.T.; Reinke, H.; Langer, P. Synthesis of tetraarylthiophenes by regioselective Suzuki cross-coupling reactions of tetrabromothiophene. Tetrahedron Lett. 2007, 48, 845-847. [CrossRef]

13. Ikram, H.M.; Rasool, N.; Zubair, M.; Khan, K.M.; Abbas Chotana, G.; Akhtar, M.N.; Abu, N.; Alitheen, N.B.; Elgorban, A.M.; Rana, U.A. Efficient Double Suzuki Cross-Coupling Reactions of 2,5-Dibromo-3-hexylthiophene: Anti-Tumor, Haemolytic, Anti-Thrombolytic and Biofilm Inhibition Studies. Molecules 2016, 21, 977. [CrossRef] [PubMed]

14. Suzuki, A. Recent advances in the cross-coupling reactions of organoboron derivatives with organic electrophiles, 1995-1998. J. Organomet. Chem. 1999, 576, 147-168. [CrossRef]

15. Frisch, M.J.; Trucks, G.W.; Schlegel, H.B.; Scuseria, G.E.; Robb, M.A.; Cheeseman, J.R.; Scalmani, G.; Barone, V.; Mennucci, B.; Petersson, G.A.; et al. Gaussian 09 Revision D. 01; Gaussian Inc.: Wallingford, CT, USA, 2010.

16. Adamo, C.; Barone, V. Toward reliable density functional methods without adjustable parameters: The PBE0 model. J. Chem. Phys. 1999, 110, 6158-6170. [CrossRef]

17. Perdew, J.P.; Burke, K.; Ernzerhof, M. Generalized Gradient Approximation Made Simple. Phys. Rev. Lett. 1996, 77, 3865-3868. [CrossRef] [PubMed]

18. Perdew, J.P.; Burke, K.; Ernzerhof, M. Generalized Gradient Approximation Made Simple. Phys. Rev. Lett. 1997, 78, 1396. [CrossRef]

19. Grimme, S. Semiempirical GGA-type density functional constructed with a long-range dispersion correction. J. Comput. Chem. 2006, 27, 1787-1799. [CrossRef] [PubMed]

20. Grimme, S.; Antony, J.; Ehrlich, S.; Krieg, H. A consistent and accurate ab initio parametrization of density functional dispersion correction (DFT-D) for the 94 elements H-Pu. J. Chem. Phys. 2010, 132, 154104. [CrossRef] [PubMed]

21. Grimme, S.; Ehrlich, S.; Goerigk, L. Effect of the damping function in dispersion corrected density functional theory. J. Comput. Chem. 2011, 32, 1456-1465. [CrossRef] [PubMed]

22. Weigend, F.; Ahlrichs, R. Balanced basis sets of split valence, triple zeta valence and quadruple zeta valence quality for H to Rn: Design and assessment of accuracy. PCCP 2005, 7, 3297-3305. [CrossRef] [PubMed]

23. Mennucci, B.; Tomasi, J. Continuum solvation models: A new approach to the problem of solute's charge distribution and cavity boundaries. J. Chem. Phys. 1997, 106, 5151-5158. [CrossRef]

24. Mennucci, B.; Cancès, E.; Tomasi, J. Evaluation of Solvent Effects in Isotropic and Anisotropic Dielectrics and in Ionic Solutions with a Unified Integral Equation Method: Theoretical Bases, Computational Implementation, and Numerical Applications. J. Phys. Chem. B 1997, 101, 10506-10517. [CrossRef]

25. Tomasi, J.; Mennucci, B.; Cammi, R. Quantum mechanical continuum solvation models. Chem. Rev. 2005, 105, 2999-3093. [CrossRef] [PubMed]

26. Mennucci, B. Polarizable Continuum Model. Wiley Interdiscip. Rev. Comput. Mol. Sci. 2012, 2, $386-404$. [CrossRef]

27. Marenich, A.V.; Cramer, C.J.; Truhlar, D.G. Universal Solvation Model Based on Solute Electron Density and on a Continuum Model of the Solvent Defined by the Bulk Dielectric Constant and Atomic Surface Tensions. J. Phys. Chem. B 2009, 113, 6378-6396. [CrossRef] [PubMed] 
28. Williams, T.; Kelley, C. Gnuplot 5.0: An Interactive Plotting Program. Official Gnuplot Documentation. 2015. Available online: http:/ / www.gnuplot.info/ (accessed on 30 July 2018).

29. Legault, C.Y. CYLview B; Université de Sherbrooke: Sherbrooke, QC, Canada, 2009; Available online: http:/ / www.cylview.org (accessed on 30 July 2018).

30. Hashmi, M.A.; Andreassend, S.K.; Keyzers, R.A.; Lein, M. Accurate prediction of the optical rotation and NMR properties for highly flexible chiral natural products. Phys. Chem. Chem. Phys. 2016, 18, 24506-24510. [CrossRef] [PubMed]

31. Marder, S.R. Organic nonlinear optical materials: Where we have been and where we are going. Chem. Commun. 2006, 2, 131-134. [CrossRef] [PubMed]

32. Champagne, B.; Plaquet, A.; Pozzo, J.-L.; Rodriguez, V.; Castet, F. Nonlinear Optical Molecular Switches as Selective Cation Sensors. J. Am. Chem. Soc. 2012, 134, 8101-8103. [CrossRef] [PubMed]

33. Burland, D. Optical Nonlinearities in Chemistry: Introduction. Chem. Rev. 1994, 94, 1-2. [CrossRef]

34. Hashmi, M.A.; Lein, M. Carbon Nano-onions as Photosensitizers: Stacking-Induced Red-Shift. J. Phys. Chem. C 2018, 122, 2422-2431. [CrossRef]

35. Arshad, M.N.; Bibi, A.; Mahmood, T.; Asiri, A.M.; Ayub, K. Synthesis, crystal structures and spectroscopic properties of triazine-based hydrazone derivatives; a comparative experimental-theoretical study. Molecules 2015, 20, 5851-5874. [CrossRef] [PubMed]

36. Ikram, H.M.; Rasool, N.; Ahmad, G.; Chotana, G.A.; Musharraf, S.G.; Zubair, M.; Rana, U.A.; Zia-Ul-Haq, M.; Jaafar, H.Z. Selective C-arylation of 2,5-dibromo-3-hexylthiophene via suzuki cross coupling reaction and their pharmacological aspects. Molecules 2015, 20, 5202-5214. [CrossRef] [PubMed]

37. Ahmad, G.; Rasool, N.; Ikram, H.M.; Gul Khan, S.; Mahmood, T.; Ayub, K.; Zubair, M.; Al-Zahrani, E.; Ali Rana, U.; Akhtar, M.N. Efficient Synthesis of Novel Pyridine-Based Derivatives via Suzuki Cross-Coupling Reaction of Commercially Available 5-Bromo-2-methylpyridin-3-amine: Quantum Mechanical Investigations and Biological Activities. Molecules 2017, 22, 190. [CrossRef] [PubMed]

(C) 2018 by the authors. Licensee MDPI, Basel, Switzerland. This article is an open access article distributed under the terms and conditions of the Creative Commons Attribution (CC BY) license (http:/ / creativecommons.org/licenses/by/4.0/). 